\title{
Defeating terrorism, piracy and armed robbery against ships in a collective maritime security system ${ }^{1}$
}

\author{
Hakan Selim Canca ${ }^{2}$
}

\begin{abstract}
With increasing global economic development, maritime security constitutes more important role throughout the world. The efforts of the international community including shipmasters, shipowners, international specialized agencies, intergovernmental organizations and States concentrate on ensuring the safety and security of ships, repressing acts of maritime violence, imposing obligations upon States, and developing regional agreements between States. As the oceans are used by all and controlled by no one ${ }^{3}$, these efforts are very important for global trade and security. Taking into account the security concerns of littoral states, the shipping industry and passengers in general, these efforts continue to try to repress the serious crimes of terrorism, piracy and armed robbery at sea while staying in the lines of the freedoms of the seas that are being protected by state practice and customary international law. In this study, the consequent codification related to the acts of terrorism, piracy and armed robbery against ships and the problems related to the measures aiming to defeat these crimes were examined and recommendations to prevent these crimes were given.
\end{abstract}

Keywords: Terrorism at Sea, Piracy and Armed Robbery against Ships, Maritime Security, Collective Security, SUA Convention, Law of the Sea, UNCLOS.

\section{Introduction}

The sea provides a formidable natural barrier between the continents, but at the same time it also provides a means of contact and communication, a navigable expanse and plentiful resource. State practice played a dramatic role in shaping the public order of the oceans and we saw efforts to

\footnotetext{
1 The views expressed in this paper are submitted in the author's personal capacity and do not necessarily represent the position of any department or agency of any government or institution.

2 PhD, Public Law (Marmara University, 2011, Istanbul); Post-doc in Max Planck Institute for Comparative Public Law and International Law, Heidelberg-Germany (2013-2014). The author would like to thank to Prof.Dr. Armin von Bogdandy for his help and support during our research in the Max Planck Institute and Prof.Dr. Yücel Acer for his help and guidance in preparing this article.

${ }^{3}$ Gabel, Jr., George D. (2007), "Smoother Seas Ahead: The Draft Guidelines as an International Solution to ModernDay Piracy", 21st Biennial Admiralty Law Institute Symposium, 81 Tul.L.Rev.1433, p.1.
} 
Canca, H. S. (2014). Defeating terrorism, piracy and armed robbery against ships in a collective maritime security system. International Journal of Human Sciences, 11(1), 1282-1300. doi: 10.14687/ijhs.v11i1.2951

codify that practice into a treaty based Law of the Sea. ${ }^{4}$ There is increasing acceptance of a common interest that exists among states when seeking to respond to maritime security threats, while the protection of sovereignity and national interests remain fundemental to maritime security. ${ }^{5}$ Following the trend away from the principle of the freedom of the high seas in the 20th century, a ship may face boardings and executive enforcement by a coastal state whose waters it enters and additionally non-flag state assertions of jurisdiction on the high seas can occure for certain activities that are so illicit that any nation may enforce their jurisdiction. ${ }^{6}$

Unlike the states' own legal systems, the international legal order does not consist of an authority to designate the rules to ensure the maritime security and at the same time use enforcement jurisdiction to make these rules obeyed by all nations. As Allen said, "the international system consists principally of sovereign states, which collectively comprise a horizontal, nonhierarchical global order that has historically been described as one of moderated anarchy, at least by the realists". 7 At this point a well-designed collective security system has a vital role to provide the safety and security of the shipping world.

The definition of security and related measures differs in various documents. Generally security aims to prevent the risks to a normal condition of any operation. For example, The IMO and ILO's Code of Practice on Security in Ports ${ }^{8}$ defines security as "a condition whereby the level of risk is deemed acceptable" and, determines the aim of port security measures as "to maintain an acceptable level of risk at all security levels."

Defeating the risks to the normal operations of the merchant shipping world and the navies, international cooperation and development of related codification of international law are very important. In the United Nations General Assembly's "Declaration on Measures to Eliminate

\footnotetext{
${ }^{4}$ Becker, Michael A. (2005), "The Shifting Public Order of the Oceans: Freedom of Navigation and the Interdiction of Ships at Sea", 46 Harvard International Law Journal 131, p.131.

${ }^{5}$ Klein, Natalie (2011), "Maritime Security and the Law of the Sea", Oxford University Press, New York, 2011, p.1.

${ }^{6}$ Brown, Thomas M. (2010), "For the "Round and Top of Sovereignity": Boarding Foreign Vessels at Sea on TerrorRelated Intelligence Tips”, 59 Naval L.Rev. 63, p.64.

${ }^{7}$ Allen, Craig H. (2008), "The Influence of Law on Sea Power Doctrines: The New Maritime Strategy and the Future of the Global Legal Order”, 84 Int'l L. Stud. Ser. US Naval War Col.3, p.7.

${ }^{8}$ http://www.oas.org/cip/english/docs\% \% Cimportant_documents\% $\%$ CILOIMOCODEDRAFTmesshp-cp-a English.pdf, p.3 (visited 29.04. 2014).

${ }^{9}$ http://www.oas.org/cip/english/docs\%5Cimportant_documents\%5CILOIMO-CODEDRAFTmesshp-cp-a English.pdf, p.5 (visited 29.04.2014)). Also some examples of the aim of security measures that may be considered are given in the code as: "a) Prevent access to the port by persons without a legitimate reason to be there and prevent those persons with legitimate reasons to be in the port from gaining illegal access to ships or other restricted port areas for the purpose of committing unlawful acts, b) Prevent introduction of unauthorized weapons, dangerous or hazardous substances and devices, into the port or vessels using the port, c) Prevent personal injury or death, or damage to the port, port facility, ship or port infrastructure by explosive or other devices, d) Prevent tampering with cargo, essential equipment, containers, utilities, protection systems, procedures and communications systems affecting the port, e) Prevent smuggling of contraband, drugs, narcotics, other illegal substances and prohibited material, f) Prevent other criminal activities, such as theft."
} 
Canca, H. S. (2014). Defeating terrorism, piracy and armed robbery against ships in a collective maritime security system. International Journal of Human Sciences, 11(1), 1282-1300. doi: 10.14687/ijhs.v11i1.2951

International Terrorism", the need for international cooperation and progressive development of internaional law and its codification is emphasized. ${ }^{10}$

As it is shown in the table below, the reports about maritime incidents sharply rised since 1996. While this data shows us the number of the reported events, the real number of the events may be more dramatic because of the events occured but not reported to an official institution due to the insurance costs, long time of delays, etc.

Figure-1: Yearly Statistics of Incidents Which Occurred Since 1984 (Worldwide). ${ }^{11}$

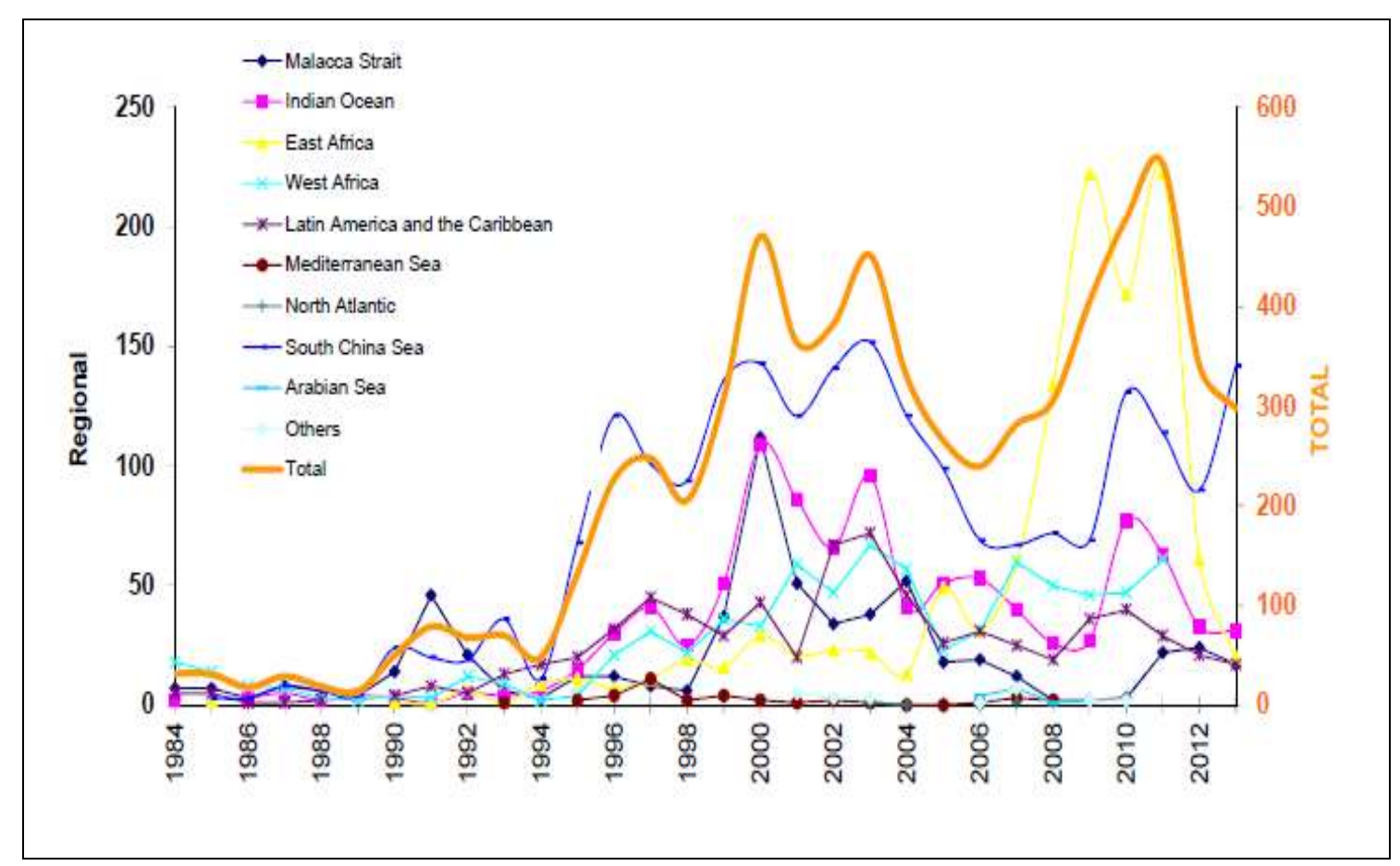

The starting point of security related measures in the maritime area should be the land territories of all states. The criminals are getting organised, supplied and supported by illegal organizations in the land territories. So a collective security understanding is a crucial point to prevent the risks to the maritime world. International efforts to improve the security of ports are crucial dealing with the problem of piracy and armed robbery against ships. In 2013, the acts of piracy and armed robbery against ships committed mostly in the port area in Indian Ocean, Malacca Strait, South America, South China Sea and Mediterranean Sea, while they were committed

10 http://www.un.org/documents/ga/res/49/a49r060.htm (visited 08.05.2013).

11 Reports on Acts of Piracy and Armed Robbery Against Ships, MSC.4/Circ.208, 1 March 2013, http:// www.imo.org/OurWork/Security/PiracyArmedRobbery/Reports/Documents/208_Annual_2013.pdf (visited 29.04.2014). 
Canca, H. S. (2014). Defeating terrorism, piracy and armed robbery against ships in a collective maritime security system. International Journal of Human Sciences, 11(1), 1282-1300. doi: 10.14687/ijhs.v11i1.2951

mostly in international waters in Arabian Sea, East Africa and West Africa as shown in the table below.

Figure-2: Regional Analysis of Reports on Acts of Piracy and Armed Robbery Against Ships Which Were Reported to Have Been Allegedly Committed or Attempted During 2013. ${ }^{12}$

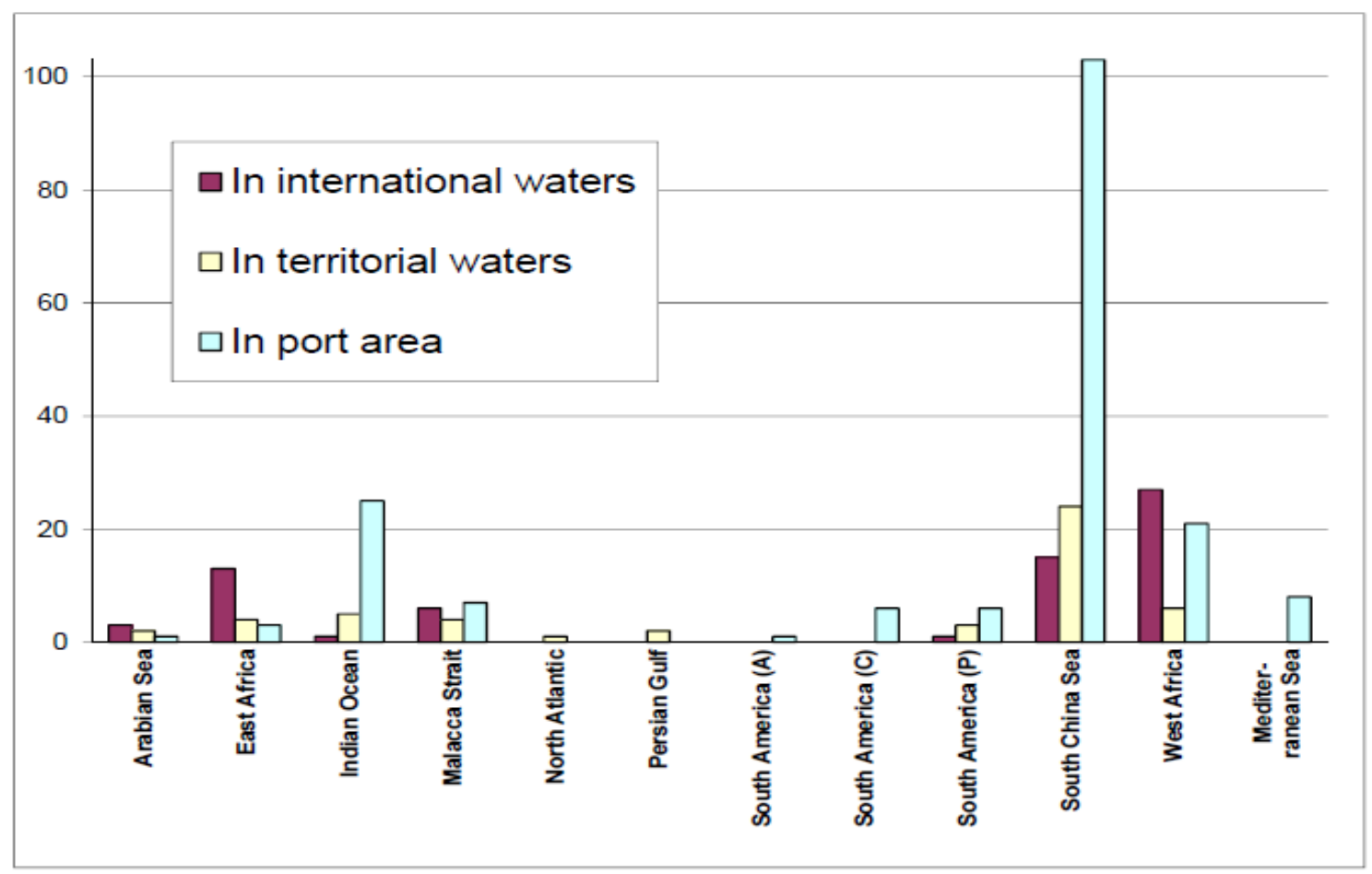

\section{Defeating Terrorism at Sea and International Law}

\subsection{Existing Framework of International Law Dealing with Terrorism at Sea}

The international community reacts to terrorism and related crimes very seriously especially after the 9/11 attacks in the U.S in 2001. Even we have seen more measures in maritime area than the land and air area after these attacks, currently only one of the international terrorism conventions deals with acts of terrorism at sea. ${ }^{13}$

\footnotetext{
12 Reports on Acts of Piracy and Armed Robbery Against Ships, MSC.4/Circ.208, 1 March 2013, http:// www.imo.org/OurWork/Security/PiracyArmedRobbery/Reports/Documents/208_Annual_2013.pdf, p.20 (visited 29.04.2014).

13 Convention for the Suppression of Unlawful Acts against the Safety of Maritime Navigation, done at Rome on 10 March 1988 (came into force on March 1, 1992) and its Protocol for the Suppression of Unlawful Acts against the Safety of Fixed Platforms Located on the Continental Shelf, done at Rome on 10 March 1988. Other conventions are; Convention on the Prevention and Punishment of Crimes against Internationally Protected Persons, Including Diplomatic Agents (14 December 1973, 1035 UNTS 167), International Convention against the Taking of Hostages (17 December 1979, 1316 UNTS 205), International Convention for the Terrorist Bombings (15 December 1997, 2149 UNTS 256), International Convention for the Suppression of the Financing of Terrorism (9 December 1999, 2178
} 
Canca, H. S. (2014). Defeating terrorism, piracy and armed robbery against ships in a collective maritime security system. International Journal of Human Sciences, 11(1), 1282-1300. doi: 10.14687/ijhs.v11i1.2951

Terrorists are increasingly being viewed as a "common enemy" just as pirates are described as hostis humani generis. But definition of terrorism remains as a serious problem in international law. Terrorism, like beauty, remains in the eye of the beholder. ${ }^{14}$ There is still no universally accepted definition of terrorism. This is one of the main problems dealing with the maritime terrorism.

Right of self-defense is an important tool while defeating terrorism in international law. Von Heinegg states that a target or a potential target state, and its allies do not have to adopt a waitand-see policy but it is possible that they take all measures reasonably necessary to prevent future attacks as early and effectively as possible and in the maritime context such preventive measures may comprise "surveillance and control of sea traffic; providing for freedom and safety of navigation; protection of endangered vessels; disruption of lines of communication; visit, search (boarding) and capture; diversion; establishment of security zones and of restricted sea areas; capture/arrest of cargoes and persons". ${ }^{15}$

\subsection{Convention for the Suppression of Unlawful Acts against the Safety of Maritime} Navigation and Its Protocol

The Convention for the Suppression of Unlawful Acts against the Safety of Maritime Navigation (SUA Convention)-1988 is an important instrument of international law defeating terrorism at sea. The convention constitutes a vital role with the Protocol singed in 2005. SUA Convention "was meant to be the answer to the worldwide escalation of acts or terrorism in various ports which endangered or took innocent human lives...". ${ }^{16}$

The SUA Convention covers unlawful acts in Article 3 such as; the seizure of ships by force; acts of violence against persons on board ships; and the placing of devices on board a ship

UNTS 197), International Convention for the Suppression of Acts of Nuclear Terrorism New York (13 April 2005 , 2445 UNTS 89), Convention on Offences and Certain Other Acts Committed on Board Aircraft (Tokyo, 14 September 1963), Convention for the Suppression of Unlawful Seizure of Aircraft (Hague, 16 December 1970), Convention for the Suppression of Unlawful Acts against the Safety of Civil Aviation (Montreal, 23 September 1971), Convention on the Physical Protection of Nuclear Material (Vienna, 3 March 1980), Protocol on the Suppression of Unlawful Acts of Violence at Airports Serving International Civil Aviation, supplementary to the Convention for the Suppression of Unlawful Acts against the Safety of Civil Aviation (Montreal, 24 February 1988), Convention on the Marking of Plastic Explosives for the Purpose of Detection (Montreal, 1 March 1991).

${ }^{14}$ Kindred, Hugh M. (2000), "International Law Chiefly as Interpreted and Applied in Canada", 6th ed. $\quad$ (Toronto: Emond Montgomery Publications Limited) at 526; in: Pathak, Monica (2005), "Maritime Violence: Piracy At Sea \& Marine Terrorism Today", 20 Windsor Rev. Legal \& Soc. Issues 73; in: "United States of America v. Mohamed Ali Said", in the United States District Court Eastern District of Virginia Norfolk Division, Criminal No.2:10cr57, p.16-17, http://www.unicri.it/topics/piracy/database/USA_2010_Crim_No_2_10cr57.pdf (visited 14.05. 2013).

15 Von Heinegg, Wolff Heintschel (2006), "Current Legal Issues in Maritime Operations: Maritime Interception Operations in the Global War on Terrorism, Exclusion Zones, Hospital Ships and Maritime Neutrality”, 80 Int'l L. Stud. Ser. US Naval War Col., p.209.

16 Prakash, K.Jaya (1999), "International Maritime Fraud: Is There a Sufficient Mechanism in Place to Combat it?" (Paper presented at the 12th Commonwealth Law Conference at Kuala Lumpur in September 1999); in: Pathak, Monica (2005), "Maritime Violence: Piracy At Sea \& Marine Terrorism Today", 20 Windsor Rev. Legal \& Soc. Issues 74-75. 
Canca, H. S. (2014). Defeating terrorism, piracy and armed robbery against ships in a collective maritime security system. International Journal of Human Sciences, 11(1), 1282-1300. doi: 10.14687/ijhs.v11i1.2951

which are likely to destroy or damage it. It is stated in the Article that; "Any person commits an offence if that person unlawfully and intentionally: a) Seizes or exercises control over a ship by force or threat thereof or any other form of intimidation; or b) Performs an act of violence against a person on board a ship if that act is likely to endanger the safe navigation of that ship; or c) Destroys a ship or causes damage to a ship or to its cargo which is likely to endanger the safe navigation of that ship; or d) Places or causes to be placed on a ship, by any means whatsoever, a device or substance which is likely to destroy that ship, or cause damage to that ship or its cargo which endangers or is likely to endanger the safe navigation of that ship; or e) Destroys or seriously damages maritime navigational facilities or seriously interferes with their operation, if any such act is likely to endanger the safe navigation of a ship; or f) Communicates information which he knows to be false, thereby endangering the safe navigation of that ship; or g) Injures or kills any person, in connection with the commission or the attempted commission of any of the offences set forth in subparagraphs (a) to (f)."

In the second paragraph of Article 3 of the SUA Convention, attempting to committing and abeting the commission the offences and threatening to commit the offences are taken into account. $^{17}$

The SUA Convention applies "if the ship is navigating or is scheduled to navigate into, through or from waters beyond the outer limit of the territorial sea of a single State, or the lateral limits of its territorial sea with adjacent States."18

The SUA Convention obliges States Parties to make the offences set forth in article 3 punishable by appropriate penalties. It does not prescribe specific penalties for any of the offences. Article 6 of the SUA Convention provides that; "1. Each State Party shall take such measures as may be necessary to establish its jurisdiction over the offences set forth in article 3 when the offence is commtited: (a) Against or on board a ship flying the flag of the State at the time the offence is committed; or (b) In the territory of that State, including its territorial sea; or (c) By a national of that State; 2. A State Party may also establish its jurisdiction over any such offence when: (a) It is committed by a stateless person whose habitual residence is in that State; or

\footnotetext{
${ }_{17}$ SUA Convention, Art.3, paragraph 2: "Any person also commits an offence if that person: (a) Attempts to commit any of the offences set forth in paragraph 1 ; or (b) Abets the commission of any of the offences set forth in paragraph 1 perpetrated by any person or is otherwise an accomplice of a person who commits such an offence; or (3) Threatens, with or without a condition, as is provided for under national law, aimed at compelling a physical or juridical person to do or refrain from doing any act, to commit any of the offences set forth in paragraph 1 , subparagraphs (b), (c) and (e), if that threat is likely to endanger the safe navigation of the ship in question."

18 SUA Convention, Art.4, paragraph 1. In paragraph 2 of the same Article, it is stated that; "In cases where the Convention does not apply persuant to paragraph 1, it nevertheless applies when the offender or the alleged offender is found in the territory of a State Party other than the State referred to in paragraph 1."
} 
Canca, H. S. (2014). Defeating terrorism, piracy and armed robbery against ships in a collective maritime security system. International Journal of Human Sciences, 11(1), 1282-1300. doi: 10.14687/ijhs.v11i1.2951

(b) During its commission a national of that State is seized, threatened, injured or killed; or (c) It is committed in an attempt to compel that State to do or abstain from doing any act."

The 2005 Protocol to the SUA Convention adds a new article 3bis which states that a person commits an offence within the meaning of the Convention if that person unlawfully and intentionally does such actions stated in the article, ${ }^{19}$ such as using explosives, transporting explosive or radioactive material on board a ship.

\subsection{International Ship and Port Facility Security Code}

The International Ship and Port Facility Security Code (ISPS Code) is a comprehensive set of measures to enhance the security of ships and port facilities. The ISPS Code is implemented through chapter XI-2 Special Measures to Enhance Maritime Security in the International Convention for the Safety of Life at Sea (SOLAS), 1974. The Code has two parts, one mandatory and one recommendatory. ${ }^{20}$

In December 2002, amendments to the SOLAS Convention and the International Ship and Port Facility Security Code (ISPS Code) were adopted by the 2002 Conference of Contracting Governments to the SOLAS Convention. Chapter XI-2 of the SOLAS Convention (SOLAS chapter XI-2) and ISPS Code together bring mandatory measures aimed at enhancing the security of ships engaged on international voyages and the port facilities which serve them.

The new Chapter XI-2 applies to passenger ships and cargo ships of 500 gross tonnage and upwards, including high speed craft, mobile offshore drilling units and port facilities serving such ships engaged on international voyages. Regulation XI-2/2 of the new chapter enshrines the ISPS Code. The regulation requires Administrations to set security levels and ensure the provision of security level information to ships entitled to fly their flag. Regulation XI-2/8 confirms the role of

\footnotetext{
19 Article 3 bis states that "a Person commits an offence within the meaning of the Convention if that person unlawfully and intentionally: 1 . When the purpose of the act, by its nature or context, is to intimidate a population, or to compel a Government or an international organization to do or to abstain from any act: a) Uses against or on a ship any explosive, radioactive material or BCN (biological, chemical, nuclear) weapon in a manner that causes or is likely to cause death or serious injury or damage; b) Discharges, from a ship, oil, liquified natural gas, or other hazardous or noxious substance, in such quantity or concentration that causes or is likely to cause death or serious injury or damage; c) uses a ship in a manner that causes death or serious injury or damage; 2 . Transports on board a ship any explosive or radioactive material, knowing that it is intended to be used to cause, or in a threat to cause, death or serious injury or damage for the purpose of intimidating a population, or compelling a Government or an international organization to do or to abstain from doing any act; 3. Transports on board a ship any BCN weapon, knowing it to be a BCN weapon; 4. Any source material, special fissionable material, or equipment or material especially designed or prepared for the processing, use or production of special fissionable material, knowing that it is intended to be used in a nuclear explosive activity or in any other nuclear activity not under safeguards pursuant to an IAEA comprehensive safeguards agreement; and 5. Transports on board a ship any equipment, materials or software or related technology that significantly contributes to the design, manufacture or delivery of a $\mathrm{BCN}$ weapon, with the intention that it will be used for such purpose."

${ }^{20}$ http://www.imo.org/OurWork/Security/Guide_to__Maritime_Security/Pages/SOLAS (visited 25.04.2013).
} 
Canca, H. S. (2014). Defeating terrorism, piracy and armed robbery against ships in a collective maritime security system. International Journal of Human Sciences, 11(1), 1282-1300. doi: 10.14687/ijhs.v11i1.2951

the Master in exercising his professional judgement over decisions necessary to maintain the security of the ship. Regulation XI-2/6 requires all ships to be provided with a ship security alert system. Regulation XI-2/10 covers requirements for port facilities, providing for Contracting Governments to ensure that port facility security assessments are carried out and that port facility security plans are developed, implemented and reviewed. ${ }^{21}$

Eleven resolutions adopted in the conference. The main points of the resolutions are outlined in the table below.

Table-1: The Main Points of the Resolutions of the 2002 Conference of Contracting Governments to the SOLAS Convention. ${ }^{22}$

\begin{tabular}{|c|c|}
\hline RES.NO. & THE MAIN POINTS OF THE RESOLUTION \\
\hline Res.1 & $\begin{array}{l}\text { Adoption of amendments to the Annex to the International Convention for the } \\
\text { Safety of Life at Sea, 1974, as amended. }\end{array}$ \\
\hline Res.2 & Adoption of the International Ship and Port Facility Security (ISPS) Code. \\
\hline Res.3 & $\begin{array}{l}\text { Further work by the International Maritime Organization pertaining to the } \\
\text { enhancement of maritime security. }\end{array}$ \\
\hline Res.4 & $\begin{array}{l}\text { Future amendments to Chapters XI- } 1 \text { and XI- } 2 \text { of the } 1974 \text { SOLAS Convention } \\
\text { on special measures to enhance maritime safety and security. }\end{array}$ \\
\hline Res.5 & Promotion of technical co-operation and assistance. \\
\hline Res.6 & Early implementation of the special measures to enhance maritime security. \\
\hline Res.7 & $\begin{array}{l}\text { Establishment of appropriate measures to enhance the security of ships, port } \\
\text { facilities, mobile offshore drilling units on location and fixed and floating } \\
\text { platforms not covered by chapter XI- } 2 \text { of the } 1974 \text { SOLAS Convention. }\end{array}$ \\
\hline Res.8 & $\begin{array}{l}\text { Enhancement of security in co-operation with the International Labour } \\
\text { Organization. }\end{array}$ \\
\hline Res.9 & Enhancement of security in co-operation with the World Customs Organization. \\
\hline Res.10 & Early implementation of long-range ships' identification and tracking. \\
\hline Res.11 & Human element-related aspects and shore leave for seafarers. \\
\hline
\end{tabular}

${ }^{21} \mathrm{http}: / /$ www.imo.org $/$ blast/mainframe.asp?topic_id=583\&doc_id=2689\# code (visited 03.05.2014).

22 loc.cit. 
Canca, H. S. (2014). Defeating terrorism, piracy and armed robbery against ships in a collective maritime security system. International Journal of Human Sciences, 11(1), 1282-1300. doi: 10.14687/ijhs.v11i1.2951

The amendments to the SOLAS Convention and the ISPS Code both have great importance in establishing an appropriate international technical framework involving co-operation between governments, government agencies, national and local administrations and the shipping and port industries to detect security threats and take preventative measures against security incidents affecting ships or port facilities used in international trade.

\subsection{International Organizations and Defeating Maritime Terrorism}

As departing from the strict flag-state jurisdiction on ships and new legal instruments give opportunity to other states to intervene on ships in different maritime areas, the international organizations become more important for the security of the maritime environment. As McLaughlin stated, "UN mandated naval interdiction operations are a standart feature of the modern international peace and security landscape". ${ }^{23}$ In its various resolutions, the United Nations urged all States to fulfill their obligations under international law and take effective and resolute measures, to become parties to related conventions and protocols, and assigned tasks and responsibilities to States and international organizations.

In its resolution 46/51 (1991), the United Nations General Assembly urged all States "to fulfill their obligations under international law and take effective and resolute measures for the speedy and final elimination of international terrorism" and requested "the other specialized agencies and intergovernmental organizations, in particular the International Maritime Organization, the Universal Postal Union, the World Tourism Organsation, the International Atomic Energy Agency and the United Nations Educational, Scientific and Cultural Organization, within their respective spheres of competence, to consider what further measures can usefully be taken to combat and eliminate terrorism." 24

After the 9/11 attacks to World Trade Centers, the United Nations Security Council resolutions 1368 (2001) and 1373 (2001) reflected international will to combat terrorism in all its forms and manifestations. By the resolutions the Security Council assigned tasks and responsibilities to States.

Resolution 59/46 of the United Nations General Assembly reaffirmed that international co-operation as well as actions by States to combat terrorism should be conducted in conformity with the principles of the Charter of the United Nations, international law and relevant

\footnotetext{
${ }^{23}$ McLaughlin, Rob (1999), "Coastal State Use of Force in the EEZ under the Law of the Sea Convention 1982 ”, 18 U. Tas. L. Rev. 11, p.277.

$24 \mathrm{http} / /$ www.un.org/ga/search/view_doc.asp?symbol=A/RES/46/51\&Lang=E\&Area=RESOLUTION (visited 07.05.2013)).
} 
Canca, H. S. (2014). Defeating terrorism, piracy and armed robbery against ships in a collective maritime security system. International Journal of Human Sciences, 11(1), 1282-1300. doi: 10.14687/ijhs.v11i1.2951

international conventions. Resolution 59/24 of the United Nations General Assembly urged States "to become parties to the Convention for the Suppression of Unlawful Acts against the Safety of Maritime Navigation and its Protocol". It invited States "to participate in the review of those instruments by the Legal Committee of the International Maritime Organization to strengthen the means of combating such unlawful acts, including terrorist acts". It also urged States "to take appropriate measures to ensure the effective implementation of those instruments, in particular through the adoption of legislation, where appropriate, aimed at ensuring that there is a proper framework for responses to incidents of armed robbery and terrorist acts at sea". ${ }^{25}$

International Maritime Organization has a very important role preventing crimes at sea. Dealing with the problem of terrorism at sea, the organization works on various measures and practical guidelines.

The resolution A.924(22) of the Assembly of the International Maritime Organization requested the revision of existing international legal and technical measures and the consideration of new measures in order to prevent and suppress terrorism against ships and to improve security aboard and ashore, and thereby to reduce the risk to passengers, crews and port personnel on board ships and in port areas and to vessels and their cargoes. ${ }^{26}$

Within the concept of the serious crimes like terrorism, piracy and armed robbery at sea, preservation and collection of evidince following an allegation of these crimes is very important. The Legal Committe of the International Maritime Organization approved draft guidelines on the preservation and collection of evidence following an allegation of a serious crime having taken place on board a ship, or following a report of a missing person from a ship, and on pastoral and medical care of victims in its 100th session, 15 to 19 April 2013. The primary purpose of the draft guidelines is described as "to assist masters in the preservation of evidence and in the pastoral and medical care of persons affected and, when appropriate, in the collection of evidence, during the period between the report or discovery of a possible serious crime and the time when law enforcement authorities or other professional crime scene investigators take action." and it includes sections covering co-operation and coordination between interested States and parties; the role of the master; missing persons; and pastoral and medical care. ${ }^{27}$

\footnotetext{
25 Preamble, Protocol of 2005 to the SUA Convention.

26 http://www.imo.org/OurWork/Security/SecDocs/Documents/Maritime\%20Security/A.924(22).pdf (visited 07.05.2013).

${ }^{27}$ http://www.imo.org/MediaCentre/PressBriefings/Pages/11-LEG-100-outcome.aspx (visited: 25.04.2013).
} 
Canca, H. S. (2014). Defeating terrorism, piracy and armed robbery against ships in a collective maritime security system. International Journal of Human Sciences, 11(1), 1282-1300. doi: 10.14687/ijhs.v11i1.2951

\section{Piracy and Armed Robbery Against Ships}

\subsection{United Nations Convention on the Law of the Sea and Piracy and Armed} Robbery Against Ships

United Nations Convention on the Law of the Sea (UNCLOS) provides the legal framework for the repression of piracy. Article 100 of the UNCLOS provides that "all States shall cooperate to the full extent in the repression of piracy on the high seas or in any other place outside the jurisdiction of any State". In order to enable themselves to co-operate effectively in the repression of piracy, States should adopt national legislation relating to piracy pursuant to the provisions of UNCLOS. ${ }^{28}$

Despite the definition in UNCLOS, ${ }^{29}$ scholars nevertheless still disagree on whether there is an authoritative definition of piracy in the international community. ${ }^{30}$ In developing the Harvard Research Draft Convention for the Law of Piracy (from which a majority of the definition of piracy for the UNCLOS was derived), the reporters stated that there was no authoritative definition. ${ }^{31}$

Article 105 of UNCLOS provides that States Parties are entitled to seize a pirate ship and arrest and seize the property on board. Such seizures may only be carried out when there exists adequate grounds for doing so (UNCLOS art.106 ${ }^{32}$ ) and only by warships or military aircraft, or other ships or aircraft clearly marked and identifiable as being on government service and authorized to that effect (UNCLOS art.107).

\footnotetext{
28 The International Maritime Organization, "Piracy: element of national legislation pursuant to the United Nations Convention on the Law of the Sea, 1982" (LEG 98/8/1 of 18 February 2011), p.1-2.

${ }^{29}$ Current definition of piracy is posited in Article 101, Part VII of the United Nations Convention on the Law of the Sea (UNCLOS)(Opened for signature Dec.10, 1982; 1833 U.N.T.S. 397) as: "Piracy is consisted of any of the following acts: (a) Any illegal acts of violence or detention, or any act of depredation, committed for private ends by the crew or the passengers of a private ship or a private aircraft, and directed: (i) On the high seas, against another ship or aircraft, or against persons or property on board such ship or aircraft; (ii) Against a ship, aircraft, persons or property in a place outside the jurisdiction of any state; (b) Any act of voluntary participation in the operation of a ship or of an aircraft with knowledge of facts making it a pirate ship or aircraft; (c) Any act inciting or of intentionally facilitating an act described in sub-paragraph (a) or (b)."

${ }^{30}$ Kindred, Hugh M. (2000), "International Law Chiefly as Interpreted and Applied in Canada", 6th ed. $\quad$ (Toronto: Emond Montgomery Publications Limited) at 526; in: Pathak, Monica (2005), "Maritime Violence: Piracy At Sea \& Marine Terrorism Today", 20 Windsor Rev. Legal \& Soc. Issues 73; in: "United States of America v. Mohamed Ali Said”, in the United States District Court Eastern District of Virginia Norfolk Division, Criminal No.2:10cr57, p.16-17, http://www.unicri.it/topics/piracy/database/USA_2010_Crim_No_2_10cr57.pdf (visited 14.05. 2013).

31 Goodwin, Joshua Michael (2006), "Universal Jurisdiction and the Pirate: Time for an Old Couple to Part", 39 Vand. J. Transnat'l L. 973, 999 (2006); in: “United States of America v. Mohamed Ali Said”, in the United States District Court Eastern District of Virginia Norfolk Division, Criminal No.2:10cr57, p.16-17, http://www.unicri.it /topics/piracy/database/USA_2010_Crim_No_2_10cr57.pdf (visited 14.05.2013).

32 UNCLOS Art.106 states that: "Where the seizure of a ship or aircraft on suspicion of piracy has been effected without adequate grounds, the State making the seizure shall be liable to the State the nationality of which is possessed by the ship or aircraft for any loss or damage caused by the seizure."
} 
Canca, H. S. (2014). Defeating terrorism, piracy and armed robbery against ships in a collective maritime security system. International Journal of Human Sciences, 11(1), 1282-1300. doi: 10.14687/ijhs.v11i1.2951

\subsection{National Jurisdictions on Piracy and Armed Robbey Against Ships and the}

\section{Need for International Cooperation}

Many of the attacks seward of the territorial sea are classified as traditional acts of piracy, over which all states may exercise jurisdiction. When the attacks occur in port or anchorage, they are most likely proscribed and punishable by the municipal criminal law of the coastal state and do not legally qualify as piracy. In the case that the unlawful acts endanger the safety of navigation and occur onboard foreign flag ships while underway in international waters, international straits or even in the territorial sea, these unlawful acts are mostly not proscribed nor punishable by the criminal laws of any intervening or coastal State.

In the exercise of universal jurisdiction, article 105 of UNCLOS provides that "the courts of the State which carried out the seizure of a pirate ship or aircraft may decide upon the penalties to be imposed, and may also determine the action to be taken with regard to the ships, aircraft or property, subject to the rights of third parties acting in good faith."

The United Nations Security Council has called upon "all States to criminalize piracy under their domestic law"133 and noted that "the domestic law of a number of States lacks provisions criminalizing piracy and/or procedural provisions for effective criminal prosecution of suspected pirates". ${ }^{34}$

The Legal Committe of the International Maritime Organization considered a number of documents which identify the key elements that may be included in national law to facilitate full implementation of international conventions applicable to piracy at its ninety-eight session (4-8 April 2011)..$^{35}$

The universal jurisdiction emphasized by UNCLOS on the crime of piracy has not been realized by States in their legal practice. Even Somalia has not criminalized piracy within its national

\footnotetext{
33 The United Nations Security Council resolution 1950(2010), paragraph 13.

34 The United Nations Security Council resolution 1918(2010), preamble.

35 http://www.un.org/Depts/los/piracy/circular_letter_3180.pdf (visited 14.05.2013). The documents had been submitted by the IMO Secretariat (Uniform and consistent application of the provisions of international conventions relating to piracy (document LEG 98/8)), the UN Division for Ocean Affairs and the Law of the Sea (UN-DOALOS) (Piracy: elements of national legislation pursuant to the United Nations Convention on the Law of the Sea, 1982 (document LEG 98/8/1 and LEG 98/8/3)), the UN Office on Drugs and Crime (UNODC) (Establishment of a legislative framework to allow for effective and efficient piracy prosecutions (document LEG 98/8/2)) and the Government of Ukraine (Establishment of a legislative framework to allow for effective and efficient piracy prosecutions (document LEG 98/8/4)). IMO Circular Letter No.3180, 17 May 2011, http://www.un.org/Depts/los/ piracy/circular_letter_3180.pdf (visited 14.05.2013).
} 
Canca, H. S. (2014). Defeating terrorism, piracy and armed robbery against ships in a collective maritime security system. International Journal of Human Sciences, 11(1), 1282-1300. doi: 10.14687/ijhs.v11i1.2951

code. ${ }^{36}$ This remains a fundamental problem in the prosecution of the criminals. According to a report, as of May 2010, "over nine out of ten captured pirates have not been prosecuted". ${ }^{37}$

Prior to 2009, the last prosecution in the United States for piracy have been in the 1885 case of The Ambrose Light, 25 F. 408 (S.D.N.Y. 1885). However, in 1922, a United States court in the Phillippine Islands affirmed an appeal from a piracy conviction in United States v. Lol-Lo and Saraw, 43 Phil.Rep. 19 (S.C. 1922) (Phil.). In 2009, the United States Government prosecuted a Saudi national for alleged piracy, resulting in a guilty plea to a seperate offense. ${ }^{38}$

Turkish courts have jurisdiction over crimes committed against Turkish vessels, while they may have jurisdiction on foreign vessels subject to a set of conditions. ${ }^{39}$ Turkish Penal Code contains both jurisdictional and substantive clauses which address acts of piracy and armed robbery at sea. Article 8 of the Turkish Penal Code extends the criminal jurisdiction of Turkish courts to offences committed within Turkish territorial sea, as well as on the open sea when Turkish flagged vessels are subject to criminal activity. Article 12 of the Code states that crimes of certain gravity

\footnotetext{
${ }^{36}$ Special Advisor to the Secretary-General, Legal Issues Related to Piracy Off the Coast of Somalia, $\mathbb{1 0 5}$, in: Kritsiotis, 2011: 342.

${ }^{37}$ Special Advisor to the Secretary-General, Legal Issues Related to Piracy Off the Coast of Somalia, 943 , in: Kritsiotis, 2011: 343 .

38 United States v. Mohammed Modin Hasan, Criminal No. 2:10cr56, United States District Court for the Eastern District of Virginia Norfolk Division, Case 2:10-cr-00056-MSD-FBS Document 178 Filed 10/29/10; Alfred P.Rubin, The Law of Piracy, 347-48\&n.107 (2d ed. 1998), http://www.unicri.it/topics/piracy/database/ USA_2010_District_Court_Crim_No_2_10cr56\%20Order.pdf (Visited May 14, 2013). In 18 U.S.C. \ 2280 Violence against maritime navigation states: "(a) Offenses; (1) In general - A person who unlawfully and intentionally- (A) seizes or exercises control over a ship by force or threat thereof or any other form of intimidation; (B) performs an act of violence against a person on board a ship if that act is likely to endanger the safe navigation of that ship; (C) destroys a ship or causes damage to a ship or to a ship or to its cargo which is likely to endanger the safe navigation of that ship; (D) place or causes to be placed on a ship, by any means whatsoever, a device or substance which is likely to destroy that ship, or cause damage to that ship or its cargo which endangers or is likely to endanger the safe navigation of that ship; (E) destroys or seriously damages maritime navigational facilities or seriously interferes with their operation, if such act is likely to endanger the safe navigation of a ship; (F) communicates information, knowing the information to be false and under circumstances in which such information may reasonably be believed, thereby endangering the safe navigation of a ship; $(G)$ injures or kills any person in connection with the commission or the attempted commission of any of the offenses set forth in subparagraphs $(\mathrm{A})$ through $(\mathrm{F})$; or $(\mathrm{H})$ attempts or conspires to do any act prohibited under sunparagraphs $(A)$ through $(G)$, shall be fined under this title, imprisoned not more than 20 years, or both; and if the death of any person reults from conduct prohibited by this paragraph, shall be punished by death or imprisoned for any term of years or for life." Other U.S. Statutes Relating to Piracy are: 18 U.S.C. $\int 1651$ Piracy under law of nations; 18 U.S.C. \ 1652 Citizens as pirates; 18 U.S.C. \ 1653 Aliens as pirates; 18 U.S.C. \1654 Arming or serving on privateers; 18 U.S.C. $\int 1655$ Assault on commander as piracy; 18 U.S.C. \1656 Conversion or surrender of vessel; 18 U.S.C. $\int 1657$ Corruption of seamen and confederating with pirates; 18 U.S.C. $\int 1658$ Plunder of distressed vessel; 18 U.S.C. $\int 1659$ Attack to plunder vessel; 18 U.S.C. $\int 1660$ Receipt of pirate property; 18 U.S.C. \1661 Robbery ashore. http://www.un.org/Depts/los/LEGISLATIONANDTREATIES/PDFFILES/USA_piracy.pdf (visited 14.05. 2013). 39 "Turkey's National Legislation with Regard to Offences Related to Piracy and Armed Robbery at Sea". http://www.un.org/Depts/los/LEGISLATIONANDTREATIES/PDFFILES/TUR_penal_criminal_procedure. pdf (visited 15.05.2013). It is stated in the document that "...10. Detention and investigation of persons who have committed piracy-related offences, are subject to the discretion of the commander of the Turkish naval ship in the area, who will use his powers in accordance with the Turkish legislation, in particular with the decision of the Turkish Grand National Assembly, n.934 of February 10, 2009, which authorizes the Government of Turkey to send naval forces to the area in question... 11. However, the position of Turkey is that the responsibility for the prosecution of piracy-related offences should remain within the countries of the region."
} 
Canca, H. S. (2014). Defeating terrorism, piracy and armed robbery against ships in a collective maritime security system. International Journal of Human Sciences, 11(1), 1282-1300. doi: 10.14687/ijhs.v11i1.2951

shall prompt the prosecution of the accused -regardless of his nationality- by Turkish courts. Paragraph 2 reads as follows: "Where the aforementioned offence is committed to the detriment of a Turkish citizen or to the detriment of a legal personality established under Turkish civil law and the offender is present in Turkey and there has been no conviction in a foreign country for the same offence then, upon the making of a complaint by the victim, he shall be subject to penalty under Turkish law." According to the Turkish Penal Code, Turkish law is to be applied to the offences of seizing control or hijacking of sea transport vehicles. Article 13(1) states: "Turkish law shall apply to the following offences committed in a foreign country whether or not committed by a citizen or non-citizen of Turkey: (...) (i) Seizing control or hijacking of air, sea or rail transport vehicles..."

\subsection{International Efforts Dealing with Piracy and Armed Robbery Against Ships}

In solving the problem of piracy and armed robbery against ships, regional co-operation among states has a significant role to play. The regional anti-piracy operation in the Straits of Malacca and Singapore is a good example of successful regional cooperation. ${ }^{41}$

To establish a sub-regional integrated coastguard network in West and Central Africa and provide the framework of co-operation and guidance for the implementation of the Network, the International Maritime Organization and the Maritime Organization of West and Central Africa (MOWCA) signed a Memorandum of Understanding in July 2008. ${ }^{42}$ In keeping with the MoU, the aim of the technical cooperation activities was stated as to create an integrated coast guard function network project and to develop it with other maritime actors in West and Central Africa and the focus is to extend West and Central African States' capabilities to implement and enforce maritime safety and security legislation and to counter piracy and armed robbery against ships and other criminal activities.

The Djibouti Code of Conduct concerning the Repression of Piracy and Armed Robbery against Ships in the Western Indian Ocean and the Gulf of Aden, was adopted as a regional agreement in Djibouti by States in the Western Indian Ocean and the Gulf of Aden in January $2009 .{ }^{43}$ The Code became effective from the date it was signed (29 January 2009). It takes into

\footnotetext{
40 http://www.un.org/Depts/los/LEGISLATIONAND-TREATIES/PDFFILES/TUR_penal_criminal_ procedure.pdf (visited 14.05.2013).

41 The Regional Cooperation Agreement on Combating Piracy and Armed Robbery against Ships in Asia (RECAAP) was concluded in November 2004 by 16 countries in Asia. The Agreement includes the RECAAP Information Sharing Centre (ISC) for facilitating the sharing of piracy-related information. "Piracy and Armed Robbery Against Ships", Initiatives to counter piracy and armed robbery at sea, http:www.imo.org/OurWork/Security/ PiracyArmedRobbery/Pages/Default.aspx (visited 02.05.2013).

42 http://www.imo.org/OurWork/Security/Guide_to_Maritime_Security/Technical-Cooperation (visited 25.04.2013).

43 Adopted in 29 January 2009 in Djibouti; signatory States (18): Comoros, Djibouti, Egypt, Eritrea, Ethiopia, Jordan,
} 
Canca, H. S. (2014). Defeating terrorism, piracy and armed robbery against ships in a collective maritime security system. International Journal of Human Sciences, 11(1), 1282-1300. doi: 10.14687/ijhs.v11i1.2951

account and promotes the implementation of those aspects of UN Security Council resolutions 1816(2008), 1838(2008), 1846(2008) and 1851(2008) and UN General Assembly resolution 63/111. According to the Code; "The signatories to the Code have agreed to co-operate, in a manner consistent with international law, in: a) The investigation, arrest and prosecution of persons, who are reasonably suspected of having committed acts of piracy and armed robbery against ships, including those inciting or intentionally facilitating such acts; b) The interdiction and seizure of suspect ships and property on board such ships; c) The rescue of ships, persons and property subject to piracy and armed robbery and the facilitation of proper care, treatment and repatriation of seafarers, fisherman, other shipboard personnel and passengers subject to such acts, particularly those who have been subjected to violence; and d) The conduct of shared operations - both among signatory States and with navies from countries outside the region - such as nominating law enforcement or other authorized officials to embark on patrol ships or aircraft of another signatory." ${ }^{44}$

The Baltic and International Maritime Council (BIMCO) ${ }^{45}$ has drawn up "Best Management Practices for Protection against Somalia Based Piracy" (BMP4) ${ }^{46}$ to assist ships to avoid, deter or delay piracy attacks in the High Risk Area (For the purpose of the BMP4 the high risk area is defined as the area where pirate activity and/or attacks have taken place and is an area bounded by Suez and the Strait of Hormuz to the North, $10^{\circ} \mathrm{S}$ and $78^{\circ} \mathrm{E} .^{47}$ ) as defined in Section 2 of the document. ${ }^{48}$ It is stated in the BMP4 that for the purpose of the BMP the term "piracy" includes all acts of violence against ships, her crew and cargo and this includes armed robbery and attempts to board and take control of the ship, wherever this may take place. ${ }^{49}$

Kenya, Madagascar, Maldives, Mauritius, Oman, Saudi Arabia, Seychelles, Somalia, Sudan, UAE, United Republic of Tanzania, Yemen. In the Status of the Implementation of The Dibouti Code of Conduct, scope of activities of the Project Implementation Unit is designated as: a) Regional Training Centre, Djibouti (DRTC), b) Information Sharing, c) National Legislation, d) Training, e) Maritime Situational Awareness, f) Project Management "Status of the Implementation of The Djibouti Code of Conduct", http:// www.imo.org / OurWork / Security / PIU / Documents / Update_paper_Dec_11. pdf(visited May 02, 2013). The Code was signed by South Africa in May 2012 and Mozambique in July 2012. With these signings the Code now has a full membership of 20 countries but France hasn't signed yet. "Djibouti Code of Conduct Project Implementation Unit", http://www.imo.org / OurWork / Security / PIU / Documents / PIU_Brochure_2nd_Edition. pdf (visited 02.05.2013).

${ }^{4}$ http://www.imo.org/OurWork/Security /PIU/Pages/DCoC. aspx (visited 02.05.2013).

45 "BIMCO is an independent international shipping association, with a membership composed of ship owners, managers, brokers, agents and many other stakeholders with vested interests in the shipping industry. The association acts on behalf of its global membership to promote higher standarts and greater harmony in regulatory matters." Available from (www.bimco.org (visited 11.04.2013)).

46 https://www.bimco.org/Security /Piracy/Piracy-regions/Gulf-of-Aden/ /media/Products/Publications /Pamphlets/BMP/BMP4-Law-Res-05-09.ashx (visited 11.04.2013).

47 ibid., p.4.

48 ibid, p.1.

${ }^{49}$ loc.cit. 
Canca, H. S. (2014). Defeating terrorism, piracy and armed robbery against ships in a collective maritime security system. International Journal of Human Sciences, 11(1), 1282-1300. doi: 10.14687/ijhs.v11i1.2951

In Section 6 of BMP4, there is a Company Planning checklist (Ibid, p.13-15) including: "(a) Prior to entering the high risk area: (1) Registering ship with The Maritime Security Centre-Horn of Africa (MSCHOA) website, (2) Obtaining the latest information from the MSCHOA and NATO Shipping Centre websites, (3) Reviewing the SSA and SSP, (4) Putting SSP in place, (5) Monitoring piracy related websites on specific threats, (6) Offering guidance to Master with regard to the recommended route, (7) Planning and installing Ship Protection Measures, (8) Conducting crew training; (b) Upon entering the High Risk Area: Submitting "Vessel Movement Registration Form" to MSCHOA."

BMP4 also focuses and gives guidance on preperations that might be within the capability of the ship's crew based on experience of piracy attacks to date and may require amendment over time if the pirates change their methods. The Ship Protection Methods (Ibid, p.23-40) include: "(a) Watchkeeping and enhanced vigilance, (b) Enhanced bridge protection, (c) Control of access to bridge, accomodation and machinery spaces, (d) Physical barriers, (e) Water spray and foam monitors, (f) Alarms, (g) Manoeuvring practice, (h) Closed circuit television (CCTV), (i) Upper deck lighting, (j) Denying use of ship's tools and equipment, (k) Protection of equipment stored on the upper deck, (I) Safe muster points / citadels, (m) Unarmed private maritime security contractors ${ }^{50}$ and (n) Armed private maritime security contractors". ${ }^{51}$

\section{Conclusion}

In securing the seas from the violance of terrorism, piracy and armed robbery against ships, existing international efforts can be considered very appropriate and successful in some aspects. But the implementation of these efforts are also very important. In this respect, States are to effectuate regulations to make the Masters and shipowners execute these measures accurately. States have to develop specialized policies against these crimes, set up inter-agency cooperation mechanisms, establish units to counter these crimes or specifically trained prosecutors and judges. Comprehensive, collaborative, multi-agency, long-term and well coordinated strategies must be operationalized.

\footnotetext{
50 The deployment of unarmed private maritime security contractors onboard is subject to the national laws of the flag state.

51 Whether to use armed Private Maritime Security Contractors on board merchant vessels or not is a matter for individual ship operators to decide following their own risk assessment and approval of respective Flag States. BMP4 Best Management Practices for Protection against Somalia Based Piracy, p.39. The United Nations Interregional Crime and Justice Research Institute (UNIRI) is developing an initiative related to the use of private security contractors on board commercial vessels with a view to preparing a set of guidelines and standarts which may be considered and a code of conduct which may guide private contractors, funded by the Government of Italy; http://www.unicri.it/topics/piracy (visited 04.05.2013).
} 
Canca, H. S. (2014). Defeating terrorism, piracy and armed robbery against ships in a collective maritime security system. International Journal of Human Sciences, 11(1), 1282-1300. doi: 10.14687/ijhs.v11i1.2951

In some countries, lack of comprehensive legislation is due to limited capacity and expertise of legislators to adopt their legislation in accordance with international instruments. To prevent the crimes committed at sea, targeted training sessions and capacity-building measures are required as a matter of priority. Although international organizations, corporations, and governmentes have attempted to solve many of the problems about sea crimes through conventions, international regulations, and bilateral or multilateral governmental agreements, many of the most crucial areas are left untouched. ${ }^{52}$

Identifying problems related to the apprehension of pirates is important for all parties involved in combating piracy or struggling with the consequences of this crime. States should share their experience in resolving problems related to apprehension of pirates and should provide related information to the international organizations dealing with such crimes.

The safety and security of mariners and the global trade depend on the safety and security of the world's seas. It is imperative that all States and that the international communities cooperate to control and suppress acts of maritime violence and terrorism. As Gentili wrote, the perpetrators of maritime crimes: "...are scorners of the law of nations; hence they find no protection in that law. They ought to be crushed by us... and all men". ${ }^{53}$

As Halberstam states, "the continued vitality of any legal system depends on its ability to deal with current problems". ${ }^{44}$ The collective security of the oceans depends on the ability of the global system to ensure a legal frame which successfully deals with the current threats to maritime security.

\section{References}

Allen, Craig H. (2008), “The Influence of Law on Sea Power Doctrines: The New Maritime Strategy and the Future of the Global Legal Order", 84 Int'l L. Stud. Ser. US Naval War Col.3.

Becker, Michael A. (2005), "The Shifting Public Order of the Oceans: Freedom of Navigation and the Interdiction of Ships at Sea", 46 Harvard International Law Journal 131.

Brown, Thomas M. (2010), "For the "Round and Top of Sovereignity": Boarding Foreign Vessels at Sea on Terror-Related Intelligence Tips", 59 Naval L.Rev. 63.

Gabel, Jr., George D. (2007), "Smoother Seas Ahead: The Draft Guidelines as an International Solution to Modern-Day Piracy", 21st Biennial Admiralty Law Institute Symposium, 81 Tul.L.Rev. 1433.

\footnotetext{
52 Steglich, Elissa (2000), "Hiding in the Hulls: Attacking the Practice of High Seas Murder of Stowaways Through Expanded Criminal Jurisdiction", 78 Tex. L. Rev. 1323, p.1.

${ }^{53}$ Keyuan, Zou (1999), "Issues of Public International Law Relating to the Crackdown of Piracy in the South China Sea and Prospects for Regional Cooperation" 3 Sing. J. Int'l\&Comp. L. 544; in: Pathak, Monica (2005), "Maritime Violence: Piracy At Sea \& Marine Terrorism Today", 20 Windsor Rev. Legal \& Soc. Issues 79.

${ }^{54}$ Halberstam, Malvina (1988), "Terrorism on the High Seas: The Achille Lauro, Piracy and the IMO Convention on Maritime Safety", The American Journal of International Law, Vol.82, No.2 (Apr. 1988), pp.269-310, Published by American Society of International Law, http://www.jstor.org/stable/2203189, p.310.
} 
Canca, H. S. (2014). Defeating terrorism, piracy and armed robbery against ships in a collective maritime security system. International Journal of Human Sciences, 11(1), 1282-1300. doi: 10.14687/ijhs.v11i1.2951

Goodwin, Joshua Michael (2006), 'Universal Jurisdiction and the Pirate: Time for an Old Couple to Part”, 39 Vand. J. Transnat'l L. 973, 999 (2006); in: "United States of America v. Mohamed Ali Said", in the United States District Court Eastern District of Virginia Norfolk Division, Criminal No.2:10cr57, p.16-17, http://www.unicri.it/topics/piracy/database/USA_2010_Crim_No_2_10cr57.pdf (visited 14.05.2013).

Halberstam, Malvina (1988), "Terrorism on the High Seas: The Achille Lauro, Piracy and the IMO Convention on Maritime Safety”, The American Journal of International Law, Vol.82, No.2 (Apr. 1988), pp.269-310, Published by American Society of International Law, http://www.jstor.org/stable/2203189.

Keyuan, Zou (1999), "Issues of Public International Law Relating to the Crackdown of Piracy in the South China Sea and Prospects for Regional Cooperation" 3 Sing. J. Int'l\&Comp. L. 544; in: Pathak, Monica (2005), "Maritime Violence: Piracy At Sea \& Marine Terrorism Today", 20 Windsor Rev. Legal \& Soc. Issues 79.

Kindred, Hugh M. (2000), "International Law Chiefly as Interpreted and Applied in Canada", 6th ed. (Toronto: Emond Montgomery Publications Limited) at 526; in: Pathak, Monica (2005), "Maritime Violence: Piracy At Sea \& Marine Terrorism Today", 20 Windsor Rev. Legal \& Soc. Issues 73; in: "United States of America v. Mohamed Ali Said", in the United States District Court Eastern District of Virginia Norfolk Division, Criminal No.2:10cr57, p.16-17, http://www.unicri.it/topics/piracy/database/USA_2010_Crim_No_2_10cr57.pdf (visited 14.05. 2013). York, 2011

Klein, Natalie (2011), "Maritime Security and the Law of the Sea", Oxford University Press, New

Kritsiotis, Dino (2011), "The Contingencies of Piracy”, California Western International Law Journal, Vol.41, Spring 2011, No.2.

McLaughlin, Rob (1999), "Coastal State Use of Force in the EEZ under the Law of the Sea Convention 1982", 18 U. Tas. L. Rev. 11.

Prakash, K.Jaya (1999), "International Maritime Fraud: Is There a Sufficient Mechanism in Place to Combat it?" (Paper presented at the 12th Commonwealth Law Conference at Kuala Lumpur in September 1999); in: Pathak, Monica (2005), "Maritime Violence: Piracy At Sea \& Marine Terrorism Today", 20 Windsor Rev. Legal \& Soc. Issues 74-75.

Steglich, Elissa (2000), "Hiding in the Hulls: Attacking the Practice of High Seas Murder of Stowaways Through Expanded Criminal Jurisdiction", 78 Tex. L. Rev. 1323.

Von Heinegg, Wolff Heintschel (2006), “Current Legal Issues in Maritime Operations: Maritime Interception Operations in the Global War on Terrorism, Exclusion Zones, Hospital Ships and Maritime Neutrality", 80 Int'l L. Stud. Ser. US Naval War Col., p.209.

Code of practice on security in ports, Tripartite Meeting of Experts on Security, Safety and Health in Ports, Geneva, 2003, http://www.oas.org/cip/english/docs\%5Cimportant _documents\%5CILOIMOCODEDRAFTmesshp-cp-aEnglish.pdf (visited 29.04.2014), p.3-5.

"Djibouti Code of Conduct Project Implementation Unit", http://www.imo.org/ OurWork/Security/PIU/Documents/PIU_Brochure_2nd_Edition. pdf (visited 02.05.2013). 04.2013).

http://www.imo.org/MediaCentre/PressBriefings/Pages/11-LEG-100-outcome.aspx (visited 25.

http://www.imo.org/OurWork/Security/Pages/MaritimeSecurity.aspx (visited 25.04. 2013).

http://www.un.org/Depts/los/LEGISLATIONANDTREATIES/PDFFILES/USA_piracy.pdf (visited 14.05.2013).

http://www.bimco.org (visited 11.04.2013).

https://www.bimco.org/Security/Piracy/Piracy-regions/Gulf-of-Aden/ /media/

Products/Publications/Pamphlets/BMP/BMP4-Law-Res-05-09.ashx) (visited 11.04.2013).

http://www.unicri.it/topics/piracy (visited 14.05.2013). 
Canca, H. S. (2014). Defeating terrorism, piracy and armed robbery against ships in a collective maritime security system. International Journal of Human Sciences, 11(1), 1282-1300. doi: 10.14687/ijhs.v11i1.2951

IMO Assembly Resolution A.924(22) 22 January 2002, adopted on 20 November 2001 (Agenda item 8), "Review of Measures and Procedures to Prevent Acts of Terrorism Which Threaten the Security of Passengers and Crew and the Safety of Ships", http://www. imo. org/OurWork/Security/SecDocs/Documents/Maritime\%20Security/A.924(22).pdf (visited 07. 05.2013).

IMO Circular Letter No.3180, 17 May 2011, http://www.un.org/Depts/los/piracy/ circular_letter_ 3180.pdf (visited 14.05.2013).

"Piracy and Armed Robbery Against Ships", Initiatives to counter piracy and armed robbery at sea, http:www.imo.org/OurWork/Security/PiracyArmedRobbery/Pages/Default. aspx (visited 02.05.2013).

Reports on Acts of Piracy and Armed Robbery Against Ships, MSC.4/Circ.208, 1 March 2013, http://www.imo.org/OurWork/Security/PiracyArmedRobbery/Reports/Documents / 208_Annual_2013.pdf (visited 29.04.2014).

"SOLAS XI-2 and the ISPS Code", http://www.imo.org/OurWork/Security/Guide_to_ Maritime_Security/ Pages/SOLAS (visited 25.04.2013).

"SUA Convention", http://www.imo.org/OurWork/Security/Guide_to_Maritime_ Security/Pages/SUA.aspx (visited 25.04.2013).

"The Djibouti Code of Conduct (Resolution 1)", http://www.imo.org/OurWork/ Security/PIU/Pages/DCoC. aspx (visited 02.05.2013).

The International Maritime Organization, "Piracy: element of national legislation pursuant to the United Nations Convention on the Law of the Sea, 1982" (LEG 98/8/1 of 18 February 2011), p.1-2.

The United Nations Security Council resolution 1950(2010), paragraph 13.

The United Nations Security Council resolution 1918(2010), preamble.

The United Nations General Assembly Resolution 46/51 "Measures to eliminate international terrorism", 9 December 1991; http://www.un.org/ga/search/view_doc.asp? symbol=A/RES/46/51\&Lang=E\&Area=RESOLUTION (visited 07.05.2013).

"Turkey's National Legislation with Regard to Offences Related to Piracy and Armed Robbery at Sea". http://www.un.org/Depts/los/LEGISLATIONANDTREATIES/ PDFFILES/TUR_penal_ criminal_procedure.pdf (visited 04.05.2013).

United Nations General Assembly Resolution A/RES/49/60, 9 December 1994, 49/60 Measures to Eliminate International Terrorism, Annex "Declaration on Measures to Eliminate International Terrorism", p.4., http://www.un.org/documents/ga/res/49/a49r060.htm (visited 08.05.2013).

"West Africa", http://www.imo.org/OurWork/Security/Guide_to_Maritime_Security/ TechnicalCooperation (visited 25.04.2013). 